\title{
Synthesis, characterization and thermal properties of thiosalicylate ionic liquids
}

\author{
CECILIA DEVI WILFRED* and FADWA BABIKER MUSTAFA \\ Fundamental and Applied Sciences Department, Universiti Teknologi PETRONAS, \\ Bandar Seri Iskandar, 31750 Tronoh, Perak, Malaysia \\ e-mail: cecili@petronas.com.my
}

MS received 23 June 2013; revised 15 August 2013; accepted 21 August 2013

\begin{abstract}
In an attempt to produce new functionalized ionic liquids, a series of thiosalicylate ionic liquids based on imidazolium, ammonium, phosphonium, choline and pyrrolidinium cations were synthesized. The compounds were characterized by Infra Red (IR), Nuclear Magnetic Resonance (NMR) and mass spectra (ESI-MS). Their glass-transition temperatures, melting points and decomposition temperatures have been measured. Physicochemical properties of ionic liquids are influenced by alkyl chain length and nature of the cation of ionic liquids.
\end{abstract}

Keywords. Thiosalicylate; imidazolium; ammonium; phosphonium; choline; pyrrolidinium.

\section{Introduction}

Ionic liquids (ILs) are organic salts that become liquids usually below about $200^{\circ} \mathrm{C}$. They are salts where the ions are poorly coordinated. At least one ion has a delocalized charge and one component is organic, which prevents the formation of a stable crystal lattice, resulting in it being liquid below $200^{\circ} \mathrm{C}$. Properties such as melting point, viscosity and solubility of starting materials and other solvents are determined by substituents on the organic component and the counter ion. Ionic liquids are non-volatile, have high thermal stability and have recently gained interest in new solvent applications such as electrochemistry, ${ }^{1,2}$ separation, ${ }^{3-5}$ synthesis ${ }^{6,7}$ and catalysis. ${ }^{8-12}$ Many ILs have been developed for specific synthetic problems. The collection of ILs based on the combinations of cations and anions has dramatically increased, and constantly new salts ${ }^{13}$ and solvent mixtures ${ }^{14}$ are prepared.

Our interest was kindled from the possibility of preparing a new interesting class of ILs from sulphurcontaining anions. There is interest in the coordination chemistry of deprotonated thiosalicylic acid and thiosalicylate, since the combination of hard carboxylate and soft thiolate donors makes it potentially able to form complexes with a wide range of metal centres. The examples in literature are limited to a few ionic liquids and there is a need to synthesis different types of ionic liquids attached to various cations.

*For correspondence
Formation of ionic liquids were carried out by quaternization of imidazole with haloalkane. Removal of excess haloalkanes and reaction solvents is generally not a problem, especially for the relatively volatile shorter chain haloalkanes. This is followed by the metathesis process which provides the desired anions of ionic liquids. ILs were also be prepared by acid/base neutralization reaction hydroxide ILs with thiosalicyalte acids. A greener method via methyl carbonate precursors was applied and precursors then reacted with acids to yield ionic liquids of interest. Seven thiosalicylate ionic liquids were prepared and their molecular structures were confirmed using ${ }^{1} \mathrm{H}$ NMR, ${ }^{13} \mathrm{C}$ NMR, IR and mass spectroscopy. Their thermal properties, i.e, decomposition temperatures, melting points and glass-transitions temperatures were recorded.

\section{Experimental}

All reagents and solvents were pure analytical grade materials purchased from commercial sources and were used without further purification. Structures of eight thiosalicylate functionalised ionic liquids are shown here in figure 1.

\subsection{Characterization of ionic liquids}

Structures of the ionic liquids were analysed by IR, NMR and ESI-MS. A Bruker Avance 300 Nuclear Magnetic Resonance Spectrophotometers was used to 


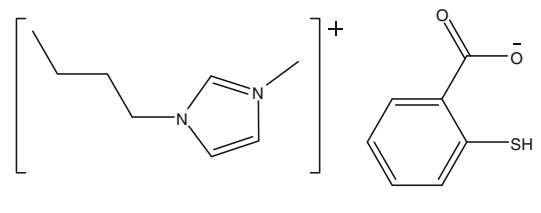

$\mathbf{I}=[$ 1-Butyl-3-methylimidazolium $]$ thiosalicylate

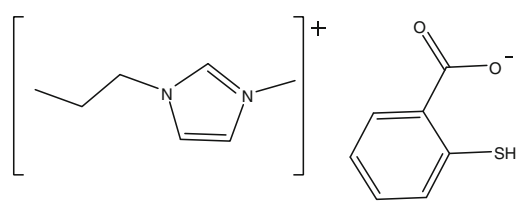

II = [1-Propyl-3-methylimidazolium $]$ thiosalicylate<smiles></smiles>

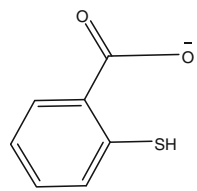

III = [1-Octyl-3-methylimidazolium $]$ thiosalicylate

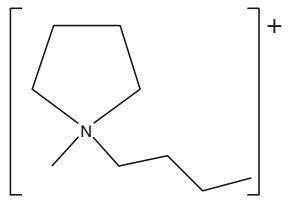

$\mathbf{I V}=[\mathrm{N}, \mathrm{N}$-methylbutylpyrrolidinium $]$ thiosalicylate

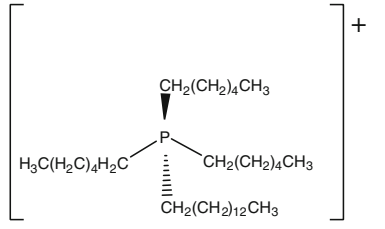

$\mathbf{V I}=[\mathrm{P} 6,6,6,14]$ thiosalicylate

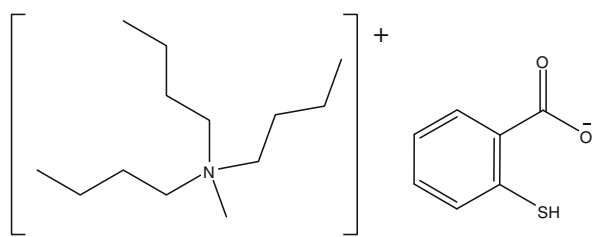

$\mathbf{V}=[$ Methyltributylammonium $]$ thiosalicylate

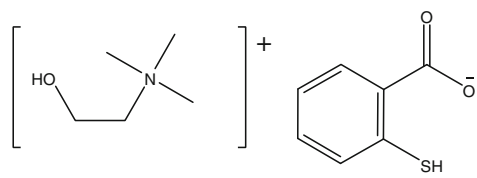

VII $=[$ Choline $]$ thiosalicylate

Figure 1. Structure of ionic liquids.

determine the ${ }^{1} \mathrm{H}$ and ${ }^{13} \mathrm{C}$ NMR spectra of ILs using DMSO- $d_{6}$. Chemical shifts were reported in parts per million (ppm) from tetramethylsilane, TMS reference ppm units with use of $\delta$ scale. Multiplicities are abbreviated as s, singlet; d, doublet; t, triplet; and $\mathrm{m}$, multiplet.

The IR spectra were recorded in a Shimadzu FTIR8400S Fourier Transform Infrared Spectrometer (FTIR) in the mid-region (4000-400 $\mathrm{cm}^{-1}$ ) using the Attenuated Total Reflectance (Miracle ATR) measurement mode. ESI-MS spectra were obtained on a Jeol-Agilent system.

Thermal stability of the synthesized ILs was investigated using a thermogravimetric analyzer (TGA, Perkin-Elmer, Pyris V-3.81) at temperatures range of $50-500^{\circ} \mathrm{C}$, heating rate of $10^{\circ} \mathrm{C} \mathrm{m^{-1 }}$ (with a temperature accuracy better than $2^{\circ} \mathrm{C}$ ) and under a nitrogen atmosphere supplied at the rate of $20 \mathrm{~mL} \mathrm{~min}^{-1}$. Glass transition temperatures, $T_{\mathrm{g}}$ and melting points, $T_{\mathrm{m}}$ were recorded on a Mettler Toledo Differential Scanning Calorimeter (DSC), model and data were evaluated using Mettler-Toledo STAR software. Measurement was carried out at a scan rate of $5^{\circ} \mathrm{C} \mathrm{min}^{-1}$.

\subsection{Preparation of thiosalicylate functionlized ionic liquids}

\section{2a [1-Butyl-3-methylimidazolium] thiosalicylate:} 1-Methylimidazole $(0.1 \mathrm{~mol})$ and 1-chlorobutane $(0.12 \mathrm{~mol})$ was added directly to a $50 \mathrm{ml}$ acetonitrile in a $250 \mathrm{ml}$ round bottommed flask equipped with a reflux condenser and magnetic stirrer. The mixture was left to stir at reflux for $48 \mathrm{~h}$. The top layer was decanted and the bottom phase was extracted thrice with ethyl actetate. The product was evaporated under reduced pressure and dried in vacuo at $70^{\circ} \mathrm{C}$ for $24 \mathrm{~h}$. Halide salts of 1-butyl-3-methylimidazolium was reacted with equimolar amount of sodium thiosalicylates in a mixture of acetone-water for $12 \mathrm{~h}$. The solvent was removed and methanol added to precipitate sodium halide salt. The salt was filtered out and the filtrate 
concentrated and dried in vacuo. Yield $76 \% .{ }^{1} \mathrm{H}$ NMR $\left(300 \mathrm{MHz}, \mathrm{DMSO}-d_{6}\right): \delta 0.89(3 \mathrm{H}, \mathrm{t}), 1.20(2 \mathrm{H}, \mathrm{t})$, $1.69(2 \mathrm{H}, \mathrm{t}), 3.69(3 \mathrm{H}, \mathrm{s}), 4.15(2 \mathrm{H}, \mathrm{d}), 6.66-6.70(2 \mathrm{H}$, m), $6.71(1 \mathrm{H}, \mathrm{m}), 6.91(1 \mathrm{H}, \mathrm{m}), 7.78(1 \mathrm{H}, \mathrm{m}), 9.33$ $(1 \mathrm{H}, \mathrm{m}) ;{ }^{13} \mathrm{C}$ NMR $(75 \mathrm{MHz}) 10.6,12.1,30.25,35.5$, $38.9,126.2,126.8,121.0,126.8,126.9,134.9,138.1$, 157.2, 169.1; IR $\left(v, \mathrm{~cm}^{-1}\right) 3396,2960,2360,1750$ 1500, 1160; ES+ mz $139\left(100 \%, \mathrm{C}_{8} \mathrm{H}_{15} \mathrm{~N}^{+}\right), \mathrm{ES}-m / z$ $153\left(100 \%, \mathrm{C}_{7} \mathrm{H}_{5} \mathrm{O}_{2} \mathrm{~S}^{+}\right)$.

\section{2b [1-Propyl-3-methylimidazolium] thiosalicylate:} Similar procedure as earlier was carried out between 1-methylimidazole and $n$-propyl chloride to give [1propyl-3-methylimidazolium] chloride. The halide salt was subjected to metathesis reaction to give the desired ionic liquid. Yield 83\%. ${ }^{1} \mathrm{H}$ NMR $(300 \mathrm{MHz}$, DMSO$\left.d_{6}\right): \delta 0.85(3 \mathrm{H}, \mathrm{t}), 1.81(2 \mathrm{H}, \mathrm{m}), 3.87(3 \mathrm{H}, \mathrm{s}), 4.13(2 \mathrm{H}$, t), $6.69(1 \mathrm{H}, \mathrm{m}), 6.93(1 \mathrm{H}, \mathrm{m}), 7.24(1 \mathrm{H}, \mathrm{m}), 7.75(2 \mathrm{H}$, m), $7.87(1 \mathrm{H}, \mathrm{m}), 9.19(1 \mathrm{H}, \mathrm{s}) ;{ }^{13} \mathrm{C}$ NMR $(75 \mathrm{MHz})$ $16.1,19.8,22.0,25.3,47.3,62.9,64.2,123.3,136.1$, 149.1, 151.2, 167.5; IR $\left(v, \mathrm{~cm}^{-1}\right) 3138,2965,1567$, 1459,$1169 ; \mathrm{ES}+m z 124\left(100 \%, \mathrm{C}_{7} \mathrm{H}_{12} \mathrm{~N}_{2}^{+}\right), \mathrm{ES}-m / z$ $153\left(100 \%, \mathrm{C}_{7} \mathrm{H}_{5} \mathrm{O}_{2} \mathrm{~S}^{+}\right)$.

2.2c [1-Octyl-3-methylimidazolium] thiosalicylate: Similar procedure as earlier was carried out between 1 -methylimidazole and $n$-octyl chloride to give [1octyl-3-methylimidazolium] chloride. The halide salts underwent metathesis reaction to give the desired ionic liquid. Yield $79 \% .{ }^{1} \mathrm{H}$ NMR $\left(300 \mathrm{MHz}, \mathrm{DMSO}-d_{6}\right): \delta$ $0.88(3 \mathrm{H}, \mathrm{t}), 1.20(2 \mathrm{H}, \mathrm{t}), 1.68-1.76(10 \mathrm{H}, \mathrm{m}), 3.72$ $(3 \mathrm{H}, \mathrm{s}), 4.18(2 \mathrm{H}, \mathrm{d}), 6.68-6.72(2 \mathrm{H}, \mathrm{m}), 6.75(1 \mathrm{H}, \mathrm{m})$, $6.92(1 \mathrm{H}, \mathrm{m}), 7.80(1 \mathrm{H}, \mathrm{m}), 9.35(1 \mathrm{H}, \mathrm{m}) ;{ }^{13} \mathrm{C} \mathrm{NMR}$ (75 MHz) 10.1, 14.2, 16.5, 19.8, 22.0, 23.2, 25.4, 27.3, 47.5, 62.6, 65.2, 124.3, 137.2, 150.1, 151.5, 168.2; IR $\left(v, \mathrm{~cm}^{-1}\right)$ 3140, 2960, 1580, 1450, 1164; ES+ mz 195 $\left(100 \%, \mathrm{C}_{12} \mathrm{H}_{23} \mathrm{~N}_{2}^{+}\right)$, ES- $m / z 153\left(100 \%, \mathrm{C}_{7} \mathrm{H}_{5} \mathrm{O}_{2} \mathrm{~S}^{+}\right)$.

2.2d [N,N-methylbutylpyrrolidinium] thiosalicylate: 1-Butylpyrrolidine was reacted with excess dimethyl carbonate in methanol in a microwave quartz reaction tube, sealed and heated with magnetic stirring to $130^{\circ} \mathrm{C}$. [ $N, N$-methylbutylpyrrolidinium] methylcarbonate. The precursor was then brought to react with thiosalicylic acid at room temperature for 4 hour. The solvent was removed and the IL dried in vacuo. Yield 84\%. ${ }^{1} \mathrm{H}$ NMR $\left(300 \mathrm{MHz}, \mathrm{DMSO}-d_{6}\right): \delta 0.98(3 \mathrm{H}, \mathrm{t})$, $1.20(2 \mathrm{H}, \mathrm{m}), 1.46(2 \mathrm{H}, \mathrm{m}), 1.87(4 \mathrm{H}, \mathrm{m}), 2.72(3 \mathrm{H}, \mathrm{s})$, $3.04(2 \mathrm{H}, \mathrm{m}), 3.14(4 \mathrm{H}, \mathrm{m}), 6.67(1 \mathrm{H}, \mathrm{m}), 6.89(1 \mathrm{H}, \mathrm{m})$, $7.25(1 \mathrm{H}, \mathrm{m}), 7.80(1 \mathrm{H}, \mathrm{m}) ;{ }^{13} \mathrm{C} \mathrm{NMR}(75 \mathrm{MHz}) 12.6$, $19.2,20.9,25.1,53.7,63.7,120.3,130.3,131.0,135.1$,
153.0, 156.0, 172.2; IR $\left(v, \mathrm{~cm}^{-1}\right) 2964,2876,1640$, $1576,1541,1441$; ES $+m z 142\left(100 \%, \mathrm{C}_{9} \mathrm{H}_{20} \mathrm{~N}^{+}\right)$, ES$m / z 152.99\left(100 \%, \mathrm{C}_{7} \mathrm{H}_{5} \mathrm{O}_{2} \mathrm{~S}^{+}\right)$.

\section{2e [Methyltributylammonium] thiosalicylate:}

Tributylamine was reacted with excess dimethyl carbonate in methanol in a microwave quartz reaction tube, sealed and heated with magnetic stirring to $140^{\circ} \mathrm{C}$. The unreacted amine was decanted and the bottom layer washed with excess ethyl acetate. The IL-precursor was then dried and brought to react with thiosalicylic acid at $\mathrm{rt}$ for $4 \mathrm{~h}$. The solvent was removed and the IL dried in vacuo. Yield $76 \% .{ }^{1} \mathrm{H}$ NMR $\left(300 \mathrm{MHz}, \mathrm{DMSO}-d_{6}\right)$ : $\delta 0.78(9 \mathrm{H}, \mathrm{t}), 1.18(6 \mathrm{H}, \mathrm{m}), 1.51(6 \mathrm{H}, \mathrm{m}), 2.77(3 \mathrm{H}, \mathrm{s})$, $3.03(6 \mathrm{H}, \mathrm{m}), 6.95-7.64(4 \mathrm{H}, \mathrm{m}) ;{ }^{13} \mathrm{C}$ NMR $(75 \mathrm{MHz})$ 13.5, 19.7, 23.9, 48.1, 61.9, 124.6, 126.1, 129.9, 130.9, 136.5, 173.3; IR $\left(v, \mathrm{~cm}^{-1}\right) 2956,2886,1645,1597$, 1530, 1449; ES+ mz $200.24\left(100 \%, \mathrm{C}_{13} \mathrm{H}_{30} \mathrm{~N}^{+}\right)$, ES$m / z 152.99\left(100 \%, \mathrm{C}_{7} \mathrm{H}_{5} \mathrm{O}_{2} \mathrm{~S}^{+}\right)$.

2.2f $\left[P_{6,6,6,14}\right]$ thiosalicylate: $\left[\mathrm{P}_{6,6,6,14}\right]$ thiosalicylate chloride was added to equimolar sodium thiosalicylates in a mixture of acetone-water for $12 \mathrm{~h}$. The solvent was removed and methanol added to precipitate the sodium halide salt. The salt was filtered out and the filtrate concentrated and dried in vacuo. Yield $72 \%$. ${ }^{1} \mathrm{H}$ NMR $\left(300 \mathrm{MHz}, \mathrm{DMSO}-d_{6}\right): \delta 0.92(12 \mathrm{H}, \mathrm{t}), 1.62$ $(48 \mathrm{H}, \mathrm{m}), 2.03(9 \mathrm{H}, \mathrm{t}), 6.60-7.80(4 \mathrm{H}, \mathrm{m}) ;{ }^{13} \mathrm{C} \mathrm{NMR}$ (75 MHz) 15.4, 18.6, 18.7, 22.4, 22.6, 36.8, 37.2, 53.4, 119.2, 120.1, 130.6, 138.4, 139.2, 158.4, 169.1; IR ( $v$, $\left.\mathrm{cm}^{-1}\right)$ 3394, 2900, 2360, $1650 \mathrm{ES}+m z 483$ (100\%, $\left.\mathrm{C}_{32} \mathrm{H}_{68} \mathrm{P}^{+}\right)$, ES- $m / z 153\left(100 \%, \mathrm{C}_{7} \mathrm{H}_{5} \mathrm{O}_{2} \mathrm{~S}^{+}\right)$.

$2.2 \mathrm{~g}$ [Choline] thiosalicylate: Equimolar concentration of choline hydroxide was reacted with thiosalicylic acid in acetone at room temperature for $2 \mathrm{~h}$. The solvent was removed and the ionic liquid dried in vacuo. Yield $83 \% .{ }^{1} \mathrm{H}$ NMR $\left(300 \mathrm{MHz}, \mathrm{DMSO}-d_{6}\right): \delta 3.16(9 \mathrm{H}, \mathrm{s})$, $3.42(2 \mathrm{H}, \mathrm{m}), 3.88(2 \mathrm{H}, \mathrm{m}), 6.80(1 \mathrm{H}, \mathrm{m}), 7.07(1 \mathrm{H}, \mathrm{m})$, $7.42(1 \mathrm{H}, \mathrm{m}), 8.02(1 \mathrm{H}, \mathrm{m}) ;{ }^{13} \mathrm{C}$ NMR $(75 \mathrm{MHz}) 54.0$, 55.3, 67.1, 120.3, 128.3, 130.7, 132.1, 136.1, 156.8, 170.7; IR $\left(v, \mathrm{~cm}^{-1}\right) 2924,2842,1560,1472,1365 ; \mathrm{ES}+$ $m z$ 104.11 (100\%, $\left.\mathrm{C}_{5} \mathrm{H}_{14} \mathrm{NO}^{+}\right)$, ES- $m / z .153 .00(100 \%$, $\left.\mathrm{C}_{7} \mathrm{H}_{5} \mathrm{O}_{2} \mathrm{~S}^{+}\right)$.

\section{Results and discussion}

\subsection{Synthesis}

Ionic liquids I, II and III were prepared via metathesis of the halide salt of the precursors. The route is straightforward, however the task of removing sodium halides 
Table 1. Thermal properties of thiosalicylate ionic liquids.

\begin{tabular}{llcc}
\hline & \multicolumn{1}{c}{ Ionic liquids } & $T_{\mathrm{dec}} /{ }^{\circ} \mathrm{C}(5 \%)$ & $T_{\mathrm{g}} /{ }^{\circ} \mathrm{C}$ \\
\hline I & [1-Butyl-3-methylimidazolium] thiosalicylate & 203.0 & -61.95 \\
II & {$[1-$ Propyl-3-methylimidazolium] thiosalicylate } & 224.0 & $-55.52,91.22^{*}$ \\
III & {$[1-$ Octyl-3-methylimidazolium] thiosalicylate } & 195.0 & -64.45 \\
IV & {$[N, N$-methylbutylpyrrolidinium] thiosalicylate } & 216.7 & -54.8 \\
V & {$[$ Methyltributylammonium] thiosalicylate } & 188.0 & -35.8 \\
VI & {$\left[\mathrm{P}_{6,6,6,14}\right]$ thiosalicylate } & 225.0 & -66.2 \\
VII & {$[$ Choline] thiosalicylate } & 187.5 & -49.5 \\
\hline
\end{tabular}

*Melting point

proved to be tedious. This is because both the ionic liquids containing sulphur and the inorganic salt have similar solubility properties in organic and aqueous solutions. Through screening the compatible solvent for precipitation, we found that sodium halides are less soluble in methanol compared to imidazolium thiosalicylates. Hence, we managed to remove the inorganic salt by adding methanol to the reaction mixture which gave the inorganic salt. The four protons of aromatic hydrogen atoms of these thiosalicylate ionic liquids had chemical shifts at $6.66-7.87 \mathrm{ppm}$. FTIR spectra of $\mathbf{I}$, II and III showed absorption bands at $\sim 1160,1466$ and 1562 which could be assigned to the stretching and bending vibrations of the aromatic $\mathrm{C}-\mathrm{H}$ group. For imidazolium, the $\mathrm{N}-\mathrm{H}, \mathrm{C}-\mathrm{H}$ and $\mathrm{C}-\mathrm{N}$ ring stretching vibrations were observed at $\sim 3156,3116$, and $1575 \mathrm{~cm}^{-1}$, respectively. The $\mathrm{C}-\mathrm{H}$ stretching vibration of $\mathrm{CH}_{2}$ was observed at $\sim 2960 \mathrm{~cm}^{-1}$.

All the ESI-MS experiments results showed a single peak at $m / z=153.2$, which could be assigned to the thiosalicylate anion.

Compounds IV and $\mathbf{V}$ were prepared from their methyl carbonate precursor as described in an earlier finding. ${ }^{15}$ An excess of dimethyl carbonate solvent with the base was heated in a microwave reactor. Without any work-up, the mixture was then brought to react with thiosalicylic acid at room temperature. The route proved easy and greener as no halide impurities would be present in the ionic liquids, hence separation step is unnecessary.

Compound VI was synthesized by exchanging the chloride ion of $\left[\mathrm{P}_{6,6,6,14}\right]$ with thiosalicylate ion. The reaction was carried out in biphasic solution as the ionic liquid produced was immiscible in water. Compound VII was easily synthesized by neutralization of choline hydroxide with thiosalicylic acid. This gave a water-soluble ionic liquid.

All the thiosalicylate-based ionic liquids studied previously ${ }^{16}$ are immiscible with water. Hydrophilicity of thiosalicyalte ionic liquids are very much dependent on the nature of the cation. Findings from this study gave water-miscible ionic liquids with the exception of $\left[\mathrm{P}_{6,6,6,14}\right]$ cation. It is predicted that hydrophobicity of an ionic liquid increases with the length of the alkyl chain on the cation. The water-miscibility character is important as these ionic liquids could be applied as water pollutant extractants.

\subsection{Thermal properties}

Thermal properties of ionic liquids are shown in table 1 .

Thiosalicylates showed glass-transition temperatures, from -66 to $-35^{\circ} \mathrm{C}$. They are highly viscous liquids, with the exception of II, which has a gellike feature at room temperature, and indicated a clear melting point at $91^{\circ} \mathrm{C}$. $\left[\mathrm{P}_{6,6,6,14]}\right.$ thiosalicylate exhibited lower glass-transition temperature than those of imidazolium, pyrrolidinium and ammonium. 1-Octyl3-methylimidazolium thiosalicylate showed lower $T_{\mathrm{g}}$ than its butyl and propyl chain cations. A longer chain attached to a imidazolium cation is speculated to show better liquidus properties than a shorter one.

The $T_{\mathrm{dec}} /{ }^{\circ} \mathrm{C}(5 \%)$ is the onset temperature which was obtained from the intersection of the baseline weight and the tangent of the weight vs temperature curve obtained from TGA analysis as decomposition occurs. From the TGA results, the imidazolium cation is more thermally stable than ammonium cation. Ngo et al. ${ }^{16}$ and Begg et al. ${ }^{17}$ reported that the imidazole is resistant to ring fission in thermal exposure. In addition, 1-propyl-3-methylimidazolium thiosalicylate cation showed better thermal stability than its octyl and butyl cations. It is suggested that the thermal stability decreases as the organic content of the molecule increases. $\left[\mathrm{P}_{6,6,6,14}\right]$ thiosalicylate, VI showed the highest thermal stability due to its cation structure.

\section{Conclusion}

Seven thiosalicylate ionic liquids have been synthesized. Their glass-transition temperatures, melting 
points and decomposition temperatures have been measured. We find a general trend in the influence of alkyl chain length and nature of cation on physicochemical properties of ionic liquids. With similar cations, ionic liquids containing 1-propyl-3-methylimidazolium cations exhibit higher melting points but lower water solubilities than those ionic liquids containing octyland butylimidazolium cations. On the other hand, imidazolium cations exhibit greater stability than ionic liquids containing ammonium cations. The most stable ionic liquids among the thiosalicylates were the phosphonium cations.

\section{Acknowledgement}

Authors thank the University Teknologi PETRONAS for providing research and library facilities.

\section{References}

1. Endres F and Abedin S Z E 2002 Chem. Commun. 892

2. Endres F and Abedin S Z E 2006 Phys. Chem. Chem. Phys. 82102

3. Huddleston J G, Willauer H D, Swatloski R P and Visser A E 1998 Chem. Commun. 1765

4. Swatloski R P, Visser A E, Reichert W M and Mayton R 2001 Chem. Commun. 135

5. Zhao H, Xia S Q and Ma P S 2005 J. Chem. Technol. Biotechnol. 801089
6. Sheldon R 2001 Chem. Commun. 2399

7. Welton T 2004 Coord. Chem. Rev. 2482459

8. Dupont J, De Souza R F and Suarez P A Z 2002 Chem. Rev. 102667

9. Gordon C M 2001 Appl. Catal. 222101

10. Wilkes J S 2004 J. Mol. Catal. A 21411

11. Huddleston J G, Visser A E, Reichert W M, Willauer H D, Broker G A and Rogers R D 2001 Green Chem. 3156

12. (a) Pandey S, Baker G A, Sze L, Pandev S, Kamath G, Zhao H and Baker S N 2013 New J. Chem. 37 909; (b) Cojocaru O A, Shamshina J L, Gurau G, Syguda A, Praczyk T, Pernak J and Rogers R D 2013 Green Chem. 15 2110; (c) Katritzky A R, Singh S, Kirichenko K, Holbrey J D, Smiglak M, Reichert W M and Rogers R D 2005 Chem. Commun. 868;(d) Fukumoto K, Yoshizawa M and Ohno H 2005 J. Am. Chem. Soc. 127 2398; (e) Carter E B, Culver S L, Fox P A, Goode R D, Ntai I, Tickell M D, Traylor R K, Hoffman N W and Davis J H 2004 Chem. Commun. 630;(f) Keglevich G, Baan Z, Hermecz I, Novak T and Odinets I L 2007 Org. Chem. 11107

13. (a) Imperato $G$, Eibler E, Niedermaier J and König B 2005 Chem. Commun. 5 1170; (b) Imperato G, König B and Chiappe C 2007 Eur. J. Org. Chem. 1049

14. Wilfred C D, Holbrey J D, Rogers R D and Shukla S 2010 Green Chem. 12407

15. Kogelnig D, Stojanovic A, Galanski M, Groessl M, Jirsa F, Krachler R and Keppler B K 2008 Tetrahedron Lett. 492782

16. Ngo H L, LeCompte K, Hargens L and McEwen A B 2000 Thermochim. Acta 35797

17. Begg C G, Grimmett M R and Wethey P D 1973 Aust. J. Chem. 262435 